Jurnal Abdimas Berdaya : Jurnal Pembelajaran, Pemberdayaan dan Pengabdian Masyarakat Volume 4 Nomor 01 Tahun 2021

P-ISSN: $2685-1563$ e-ISSN: 2720 - 9768

\title{
Pemanfaatan Jerami Padi sebagai Pakan Ternak Mengunakan Metode Silase di Desa Kelorarum Kecamatan Tikung Lamongan
}

\section{Utilization of Rice Straw as Animal Feed Using the Silage Method in Kelorarum Village, Tikung District, Lamongan}

\author{
Mimatun Nasihah ${ }^{1}$, Selvy Hani Putri Pratiwi ${ }^{2}$ \\ ${ }_{1,2}$ Universita Islam Lamongan \\ e-mail: ${ }^{1}$ mima@unisla,ac.id, ${ }^{2}$ silvyhani@gmail.com
}

\begin{abstract}
Abstrak: Desa Kelorarum berada di Kecamatan Tikung Kabupaten Lamongan. Lahan pertanian Desa ini terluas di wilayah Kecamatan Tikung, akan tetapi limbah pertanian berupa jerami padi tidak dimanfaatkan oleh warga dan cenderung menjadi sampah. Selain pertanian, Peternakan merupakan sumber mata penghasilan ke-dua masyarakat. Peternak biasanya menggunakan kangkung sebagai pakan akan tetapi sering terjadi kendala negatif, misalnya kejadian ternak warga yang tiba-tiba mati. Sejauh ini masyarakat kesulitan memilih pakan yang baik untuk ternaknya. Salah satu alternatif yang bisa ditawarkan untuk mengatasi masalah tersebut adalah memanfaatkan jerami padi sebagai pakan ternak dengan menggunakan metode silase. Solusi yang di tawarkan adalah melalui kegiatan pendidikan dan pelatihan memanfaatkan jerami padi sebagai pakan ternak mengunakan metode silase. Pengabdian masyarakat ini menggunakan metode deskriptif yang berarti pemecahan masalah yang diselidiki dengan menggambarkan keadaan obyek atau subyek pengabdian masyarakat baik itu seseorang maupun masyarakat. Hasil pengabdian masyarakat ini adalah perubahan pemahaman dan kebiasaan masyarakat dalam memanfaatkan limbah jerami, sejauh ini masyarakat sangat kurang pemahamanya tentang pemanfaatan limbah jerami sebagai pakan ternak mengunakan metode silase, petani tidak mengerti kalau jerami padi bermanfaat untuk pakan ternak yang mereka buang bisa dimanfaatkan lagi.
\end{abstract}

Kata Kunci: Limbah Jerami, Pakan Ternak, Silase

\begin{abstract}
Kelorarum Village is in Tikung District, Lamongan Regency. The kelorarum village's agricultural land is the largest in the Tikung District area, however agricultural waste in the form of rice straw is not used by residents and tends to become garbage. Apart from agriculture, Animal husbandry is the second source of income for the community. Breeders usually use water spinach as feed, but there are often negative obstacles on the farm, for example the incidence of livestock suddenly dying. So far people have had difficulty choosing good feed for their livestock. One alternative that can be offered to overcome this problem is to use rice straw as animal feed using the silage method. The solution offered is through educational and training activities utilization rice straw as animal feed using the silage method. This community service uses descriptive method which means solving problems that are investigated by describing the state of the object or subject of community service, be it a person or society. The result of this community service is a change in the understanding and habits of the community in utilizing straw waste, so far the community has very little understanding of the use of straw waste as animal feed using the silalse method. farmers do not understand that rice straw is useful for animal feed, which they throw away can produce or can be used again.
\end{abstract}

Keywords: Straw Waste, Animal Feed, Silage 


\section{A. Pendahuluan}

Desa Kelorarum merupakan salah satu desa yang ada di wilayah Kecamatan Tikung Kabupaten Lamongan tepanya di sebelah utara Kecamatan Mantup. Desa ini memiliki Lahan Pertanian yang cukup luas di daerah kelorarum ini. Desa Kelorarum diitari oleh lahan pertanian warga. Luas lahan pertanian Desa Kelorarum ini merupakan lahan terluas di wilayah kecamatan Tikung. Desa Kelorarum mempunyai kekurangan yaitu dari segi peternakan dan kelebihanya pada lahan pertanian yang menghasilkan limbah jerami padi yang tidak di manfaatkan oleh warga Desa Kelorarum. Peternakan warga Desa Kelorarum ini merupakan sumbar mata penghasilan ke dua di Desa Kelorarum. Masyarakat Desa Kelorarum ini menggantungkan pakan ternak dari kangkung. Kendala yang dihadapi pada peternakan yaitu banyak kejadian ternak warga yang tiba-tiba mati. Masyarakat kesulitan untuk memilih pakan peternakan yang baik untuk ternaknya.

Limbah sisa hasil pertanian jika tidak dimanfaatkan lambat laun akan menimbulkan masalah besar bagi lingkungan disekitar Desa Kelorarum khususnya limbah pertanian. Berdasarkan kelompoknya limbah pertanian dibagi menjadi dua yaitu limbah pertanian pra panen, dan limbah pertanian paska panen. Sedangkan Limbah pertanian berdasarkan klasifikasinya adalah limbah padat pertanian seperti sisa batang, daun, ranting yang di bakar begitu saja. Kondisi ini pada akhirnya menyebabkan pencemaran lingkungan dan berdampak pada penurunan kesehatan manusia, hilangnya habitat alami, tercemarnya sumber-sumber air serta mengakibatkan kerugian sosial dan ekonomi yang cukup besar.

Upaya yang dapat dilakukan untuk meminimalisir dampak negatif yang ditimbulkan dari limbah tersebut dan untuk meningkatkan nilai tambah bagi limbah, maka limbah-limbah harus dikelola dengan baik. Pengelolaan limbah pertanian akan menghasilkan sumberdaya dalam bentuk lain yang bermanfaat untuk berbagai jenis keperluan, baik sebagai pupuk organik bagi tanaman, atau sebagai pakan ternak.

Oleh Karena itu, perlu dilakukan upaya intensif untuk memanfaatkan limbah jerami padi. Salah satu upaya pemanfaatan limbah jerami padi adalah dijadikan sebabagi pakan ternak, pengolahan ini menggunakan metode silase. Metode silase merupakan metode dengan memanfaatkan pakan hijauan ternak yang diawetkan yang disimpan dalam kantong plastik yang kedap udara atau silo, drum, dan sudah terjadi proses fermentasi dalam keadaan tanpa udara atau anaerob.

Pemanfaatan jerami padi mengunakan metode silase ini bisa untuk menguranggi resiko angka kematian hewan ternak, dan tidak kesulitan untuk mencari pakan ternak lagi, selain itu pakan ini bisa dimanfaatkan dalam waktu yang lama. Selama ini Masyarakat Kelorarum tidak mempunyai ide untuk memanfaatkan jerami padi untuk pakan hewan ternak, Meski mereka mengalami kesulitan ide untuk mencar makan untuk hewan ternaknya. Seperti diketahui juga pakan hewan ternak Kelorarum penting untuk hewan ternaknya, Sehingga kegiatan memanfaatkan limbah jerami padi ini bisa menguranggi pencemaran lingkungan dan dapat di manfaatkan sebagai pakan ternak 
warga Kelorarum, yang melihat potensi jerami padi yang tidak di manfaatkan warga sekitar maka bisa di gunakan untuk pakan ternak mengunakan metode silase yang akan bertahan lama limbah tersebut, untuk pakan ternak.

Salah satu alternatif yang bisa ditawarkan adalah memanfaatkan jerami padi sebagai pakan ternak mengunakan metode silase, Sehingga masalah yang dihadapi masyarakat Desa Kelorarum ini bisa teratasi. Solusi yang di tawarkan adalah dengan melalui kegiatan Pendidikan dan Pelatihan Pemanfatan Limbah Jerami Padi sebagai Pakan Ternak dengan Mengunakan Metode Silase.

\section{B. Metode}

Metode dalam pengabdian masyarakat yang kami lakukan adalah metode deskriptif yang berarti pemecahan masalah yang kami selidiki dengan menggambarkan keadaan obyek atau subyek pengabdian masyarakat baik itu seseorang maupun masyarakat. Selanjutnya data yang diperoleh dengan menggunakan diskusi tanya jawab secara mendalam terhadap kepala desa Kelorarum, perangkat desa dan petani-petani dan peternak yang tergabung dalam kelompok tani dan peternak di desa Kelorarum.

Observasi desktiptif, kami lakukan pada saat memasuki keadaan sosial sebagai obyek penelitian. Pada tahapan ini, kesimpulan yang dapat kami dapat dari observasi untuk mengumpulkan data potensi dan permasalahan yang ada di desa Kelorarum serta kegiatan masyarakat yang berhubungan dengan limbah jerami sisa hasil pertanian mereka.

Observasi yang dilakukan meliputi kegiatan kegiatan sistematis yang melibatkan tim dari mahasiswa Program Studi Kesehatan Lingkungan sebagai pengamat dan partisipan untuk mengenali situasi dan keadaan dengan lebih baik.

Khalayak sasaran yang mendapatakan pendidikan dan pelatihan ini adalah Semua masyarakat Desa Kelorarum terutama kelompok tani, peternak dan perangkat desa Kelorarumr Kecamatan Tikung Lamongan.

\section{Hasil dan Pembahasan}

\section{Ternak Ruminansia}

Ternak ruminansia (pemamah biak) meliputi sapi, kerbau, kambing, dan domba mempunyai peranan yang sangat strategis bagi kehidupan ekonomi petani di pedesaan. Oleh karena itu, pemenuhan kebutuhan gizi ternak perlu diperhatikan melalui pemberian bahan pakan sesuai sesuai kebutuhan hidupnya.

\section{Limbah Jerami}

Jerami padi merupakan salah satu limbah pertanian yang cukup besar jumlahnya dan belum sepenuhnya dimanfaatkan. Produksi jerami padi bervariasi yaitu dapat mencapai 12-1 5 ton per hektar satu kali panen atau 4-5 ton bahan kering tergantung pada lokasi dan jenis varietas tanaman yang digunakan. Soekoharto (1990) menyatakan bahwa jerami padi adalah bagian tanaman padi yang sudah diambil buahnya, di 
dalamnya termasuk batang, daun, dan merang. Produksi jerami padi yang dihasilkan sekitar $50 \%$ dari produksi gabah kering panen.

Menurut Tillman dkk. (1991) jerami termasuk makanan kasar (roughate) yaitu bahan makanan yang berasal dari limbah pertanian/tanaman yang sudah dipanen. Bila ditinjau dari kandungan nutrisinya, jerami memiliki kandungan protein dan daya cerna yang rendah, namun di dalamnya memiliki sekitar $80 \%$ zat-zat potensial yang dapat dicerna sebagai sumber energi bagi ternak (Komar, 1984).

Kandungan protein yang rendah dengan daya cerna yang hanya $40 \%$ menyebabkan rendahnya konsumsi bahan kering (kurang dari $2 \%$ berat badan ternak). Hal ini jelas, tanpa penambahan konsentrat tidak mungkin dapat meningkatkan produksi ternak, bahkan mungkin dapat menurunkan produksi. Kendala lain yang mempengaruhi kualitas jerami adalah tingginya kandungan lignin dan silika sehingga menyebabkan daya cerna ransum jadi rendah (Kohar, 1984).

Kandungan lignin, sellulosa, hemisellulosa mempengaruhi kecernaan makanan dan diketahui bahwa antara kandungan lignin dan kecernaan bahan kering berhubungan sangat erat terutama pada rumput-rumputan (Jaffar dan Hassan, 1990). Lignin dan selulosa sering membentuk senyawa lignoselulose dalam dinding sel tanaman dan merupakan suatu ikatan yang kuat (Sutardi, 1980). Ditambahkan Djajanegara (1986), kecernaan serat pakan bukan hanya ditentukan oleh kandungan lignin tetapi juga ditentukan oleh ikatan lignin dengan gugus karbohidrat lainnya. Kadar serat yang tinggi dapat menganggu pencernaan zat-zat lainnya, akibatnya tingkat kecernaan menjadi menurun (Lubis, 1963).

Selulosa tidak dapat dicerna dan tidak dapat digunakan sebagai bahan makanan kecuali pada ternak ruminansia yang mempunyai mikroorganisme selulolitik dalam rumennya. Mikroba tersebut dapat mencerna selulosa dan memungkinkan hasil akhir dari pencernaan bermanfaat bagi ternak tersebut. Pada proses pencernaan selulosa tersebut banyak energi yang hilang. Dengan demikian, zat makanan tersebut memiliki nilai gizi yang rendah dibanding zat pati yang mudah dicerna (Anggorodi, 1979).

\section{Metode Silase}

Metode silase merupakan metode yang memanfaatkan pakan hijauan ternak yang diawetkan yang disimpan dalam kantong plastik yang kedap udara atau silo, drum dan sudah terjadi proses fermentasi dalam keadaan tanpa udara atau anaerob. Proses silase ini melibatkan bakteri-bakteri atau mikroba yang membentuk asam susu, yaitu Lactis acidi dan Streptococcus yang hidup secara anerob dengan derajat keasaman 4(pH 4). Oleh karena itu saat proses silase pakan hijauan ternak yang tersimpan dalam kantong plastik atau dalam silo harus ditutup rapat, sehingga proses silase berjalan dengan baik dan pakan hijauan tidak cepat dibusukkan oleh bakteri lain dan jamur.

Tujuan membuat silase sebagai pakan ternak antara lain: sebagai cadangan dan persediaan pakan ternak pada saaat musim tanpa penghujan (kemarau) yang panjang karena silase dapat bertahan dalam waktu yang lama, untuk meyimpan dan menampung pakan hijauan yang berlebih pada saat musim hujan, sehingga dapat digunakan sewaktu- 
waktu pada saat musim kemarau, memanfaatkan pakan hijauan pada saat kondisi dengan nilai nutrisi terbaik seperti protein yang tinggi, mendayagunakan sumber pakan dari sisa limbah pertanian ataupun hasil agroindustri pertanian dan perkebunan seperti bekatul, dedak, bungkil sawit, ampasa tahu,tumpi jagung, janggel jagung.

Proses membuat silase:

Bahan-bahan yang perlu dipersiapkan untuk membuat silase adalah :

1. Tetes tebu(molasses $)=3 \%$ dari bahan silase

2. Dedak hulus $=5 \%$ dari bahan silase

3. Menir $=3.5 \%$ dari bahan silase

4. Onggok $=3 \%$ dari bahan silase

5. Rumput Gajah atau hijauan sebagai bahan silase

6. Silo atau kantong plastik

Cara membuat Silase

1. Limbah jerami padi dipotong dengan ukuran 5-10 cm dengan menggunakan parang, atau dengan menggunakan mesin chopper. Potongan rumput yang kecil tujuannya agar rumput yang dimasukkan dalam silo dalam keadaan rapat dan padat sehingga tidak ada ruang untuk oksigen dan air yang masuk.

2. Semua bahan pakan dicampur hingga menjadi satu campuran.

3. Bahan pakan ternak tersebut dimasukkan dalam silo dan sekaligus dipadatkan sehingga tidak ada rongga udara.

4. Bahan pakan ternak dimasukkan sampai melebihi permukaan silo untuk menjaga kemungkinan terjadinya penyusutan isi dari silo dan tidak ada ruang kosong antara tutup silo dan permukaan pakan paling atas.

5. Setelah pakan hijauan dimasukkan semua, diberikan lembaran plastik dan ditutup rapat, dan diberi pemberat seperti batu, atau kantong plastik, atau kantong plastik yang diisi dengan Tanah.

Cara pengambilan silase:

1. Sesudah (3) minggu proses ensilase telah selasai, dan silo dapat dibongkar, selanjutnya diambil ensilasenyas. Proses silase yang benar dapat bertahan satu sampai dua (1-2) tahun, bahkan lebih.

2. Pengambilan silase secukupnya untuk pakan ternak, contonya untuk 3-5 hari.

3. Silase yang baru dibongkar sebaiknya dijemur atau diangin-anginkan terlebih dahulu.

4. Jangan sering-sering membuka silo untuk mengabil silase, ambil seperlunya, dan tutup rapat kembali silasesnya, agar silesa tidak mudah rusak

Ciri-ciri silase yang baik:

1. Rasa dan wanginya asam

2. Warna pakan ternak masih hijau

3. Teskstur rumput masih jelas

4. Tidak berjamur, tidak berlendir, dan mengumpal 


\section{Tanggapan Masyarakat}

Kegiatan Pendidikan dan Pelatihan Pemanfatan Limbah Jerami Padi sebagai Pakan Ternak dengan Metode Silase di Desa Kelorarum Kecamatan Tikung meliputi kegiatan pemaparan teori, praktik pemanfaatan limbah jerami sebagai pakan ternak mengunakan metode silalse dan tanya jawab.

Teori yang disampaikan meliputi bagaimana upaya praktik pemanfaatan limbah jerami sebagai pakan ternak mengunakan metode silalse, ini bukan pekerjaan sulit, tidak membutuhkan "kepintaran" akan tetapi membutuhkan "kemauan" saja. Diharapkan cara sederhana terkait pemanfaatan limbah jerami sebagai pakan ternak mengunakan metode silalse ini dapat dipraktikkan di rumah masing-masing warga.

Dalam mengikuti kegiatan Pendidikan dan Pelatihan Pemanfatan Limbah Jerami padi sebagai Pakan Ternak dengan Menggunakan Metode Silase ini masyarakat sangat antusias terhadap kegiatan pendidikan dan pelatihan tersebut, hal ini disebabkan karena baru pertama kali ini ada kegiatan ini, sejauh ini masyarakat sangat kurang pemahamanya tentang pemanfaatan limbah jerami sebagai pakan ternak mengunakan metode silalse, petani tidak mengerti kalau jerami padi bermanfaat untuk pakan ternak yang mereka buang bisa menghasilkan atau bisa dimanfaatkan lagi, selain itu juga pemanfatan limbah jerami ini juga bisa mengatasi masalah yang selama ini dialami oleh peternak yakni pemberian pakan pada ternak mereka, dengan memanfaatkan limbah jerami sebagai pakan, peternak tidak lagi mengalami kesulitan dalam mencari dan mendapatkan pakan yang baik bagi hewan ternak mereka.

Sejuah ini masyarakat tidak pernah melakukan kegiatan tersebut, bahkan sebagian dari mereka tidak mengerti bahwa pemanfaatan limbah jerami sebagai pakan ternak mengunakan metode silalse mempunyai manfaat yang sangat besar untuk peternak dan meningkatkan produktivitas hasil pertanian mereka. Baik pemerintah desa maupun masyarakat sangat antusias dalam mengikuti kegiatan pemanfaatan limbah jerami sebagai pakan ternak mengunakan metode silase.

\section{Simpulan}

Jerami Padi dan Pakan ternak merupakan salah satu masalah yang dialami oleh masyarakat Desa Kelorarum Kecamatan Tikung Kabupaten Lamongan. Lahan pertanian kalau tidak di jaga dan dimanfaatkan akan menjadi masalah juga. Alternatif untuk mengatasi masalah tersebut adalah dengan pemanfaatan limbah jerami sebagai pakan ternak mengunakan metode silalse.

Kegiatan yang kami lakukan adalah pendidikan dan pelatihan Pengolahan Limbah Jerami padi sebagai Pakan Ternak Menggunakan Metode Silase dengan sasaran warga masyarakat desa Kelorarum. Antusiasme masyarakat cukup tinggi dan mendapatkan sambutan yang positif baik dari perangkat desa maupun masyarakat.

Upaya memberdayakan dan menggerakkan masyarakat menjadi hal yang paling penting karena meski diadakan pelatihan seperti ini kalua masyarakat tidak mau 
bergerak untuk merubah kebiasaan lama dengan membiarkan maka tidak akan ada perbaikan lingkungan untuk kedepannya. 


\section{Daftar Rujukan}

Komar, A. 1984. Teknologi Pengolahan Jerami Sebagai Makanan Ternak. Yayasan Dian Grahita. Bandung

Lubis. D.A. 1963. Ilmu Makanan Ternak. PT. Pembangunan. Jakarta

Rukmana, R. 2005. Rumput Unggul Hijauan Makanan Ternak. Kanisius. Yogyakarta

Safan, dkk. 2008. Produksi Enzim Selulosa Oleh Aspergillus niger Menggunakan Substrat Jerami Padi Dengan Sistem Fermentasi Padat. Jurusan Teknik Kimia Fakultas Teknik UNDIP Semarang Jl. Prof. Sudarto, SH Kampus Tembalang Semarang 50236.

Sutardi, T. 1980. Landasan Ilmu Nutrisi. Jilid I. departemen Ilmu Makanan Ternak. Fakultas Peternakan. Institut Pertanian Bogor. Bogor 